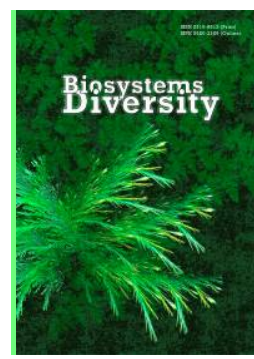

\title{
Bioremoval of hazardous cobalt, nickel, chromium, copper and cadmium compounds from contaminated soil by Nicotiana tabacum plants and associated microbiome
}

\author{
O. A. Havryliuk*, V. M. Hovorukha*, A. V. Sachko**, G. V. Gladka*, I. O. Bida*, O. B. Tashyrev* \\ *Zabolotny Institute of Microbiology and Virology of the NASU, Kyiv, Ukraine \\ **Yuriy Fedkovych Chernivtsi National University, Chernivtsi, Ukraine
}

Article info

Received 14.03.2021

Received in revised form 10.04 .2021

Accepted 12.04.2021

Zabolotny Institute

of Microbiology

and Virology of the NASU

Acad. Zabolotnogo st., 154,

Kyiv, 03143, Ukraine.

Tel.: +38-093-766-13-77.

E-mail:gav_olesya@ukr.net

Yuriy Fedkovych

Chernivtsi National

University,

Kotsjubynskyist., 2

Chernivtsi, 58012, Ukraine

Tel.: +38-067-279-40-00.

E-mail:

ansachko@gmail.com

\begin{abstract}
Havryliuk, O. A., Hovorukha, V. M., Sachko, A. V., Gladka, G. V., Bida, I. O., \& Tashyrev, O. B. (2021). Bioremoval of hazardous cobalt, nickel, chromium, copper and cadmium compounds from contaminated soil by Nicotiana tabacum plants and associated microbiome. Biosystems Diversity, 29(2), 88-93. doi:10.15421/012112
\end{abstract}

Contamination of soils with heavy metals leads to reduction of soil fertility, destruction of natural ecosystems and detrimental effects on the health of society by increasing content of metals in the food chains from microorganisms to plants, animals and humans. Bioremediation is one of the most promising and cost-effective methods of cleaning soils polluted with toxic metals. According to current researchers, microorganisms and plants have the genetic potential to remove toxic metals from contaminated sites. The method of thermodynamic prediction was used to theoretically substantiate the mechanisms of interaction of soil microorganisms and plants with heavy metals. According to the our prediction, exometabolite chelators of anaerobic microorganisms may increase the mobility of metals and thereby contribute to the active transport of metals and their accumulation in plants. Plants of Nicotiana tabacum L. of Djubek cultivar were used as plant material for the current investigation. The examined toxicants were heavy metals, namely cobalt (II), nickel (II), chromium (VI), copper (II) and cadmium (II). The aqueous solutions of metal salts were added to the boxes after two months of plants growing to the final super-high concentration $-500 \mathrm{mg} / \mathrm{kg}$ of absolutely dry weight of soil. Quantitative assessments of copper and chromium-resistant microorganisms were made by cultivation on agar nutrient medium NA with a gradient of $\mathrm{Cu}(\mathrm{II})$ and $\mathrm{Cr}(\mathrm{VI})$. The concentration of metals in soil and plant material (leaves, stems and roots) was determined by atomic absorption method. The study revealed that heavy metals inhibited the growth of the examined tobacco plants. This was expressed by the necrosis of plant tissues and, ultimately, their complete death. Despite this, all investigated heavy metals were accumulated in plant tissues during 3-7 days before death of plants. The uptake of metals was observed in all parts of plants - leaves, stems and roots. The highest concentrations of $\mathrm{Co}$ (II), $\mathrm{Ni}$ (II), $\mathrm{Cd}$ (II), $\mathrm{Cr}$ (VI) were found in the leaves, $\mathrm{Cu}(\mathrm{II})$ - in the roots. The results show that the bioremoval efficiency of the investigated metals ranged $0.60-3.65 \%$. Given the super-high initial concentration of each of the metals $(500 \mathrm{mg} / \mathrm{kg})$, the determined removal efficiency was also high. Cadmium was the most toxic to plants. Thus, the basic points of the thermodynamic prognosis of the possibility of accumulation of heavy metals by phytomicrobial consortium were experimentally confirmed on the example of $N$. tabacum plants and metal-resistant microorganisms. The study demonstrated that despite the high initial metals concentration, rate of damage and death of plants, metals are accumulated inplant tissues in extremely hight concentrations. Soil microorganisms were observed to have high adaptation potencial to $\mathrm{Cu}$ (II) and $\mathrm{Cr}(\mathrm{VI})$. In anaerobic conditions, microorganisms presumably mobilize heavy metals, which later are absorbed by plants. The obtained results are the basis for the development of environmental biotechnologies for cleaning contaminated soils from heavy metal compounds.

Keywords: thermodynamic prognosis; heavy metals contamination; metal-resistant microorganisms; environmental biotechnology.

\section{Introduction}

Contamination of soils with heavy metals is one of the most pressing problems of our time (Masindi \& Muedi, 2018). It leads to reduction of soil fertility, destruction of natural ecosystems and detrimental effects on the health of society through the circulation in the food chain between microorganisms, plants, animals and humans (Xiao et al., 2017). The natural and anthropogenic processes are the main sources of metal pollution (Aleksandra, 2011). The first type includes erosion and weathering of the underlying bedrock (Aleksandra, 2011). The second includes human industrial activities, in particular industrial metals mining (Fashola et al., 2016; Sun et al., 2018) and the use of metal-containing pesticides and fungicides to control agricultural diseases (Husak, 2015). The methods of soil remediation are divided into ex situ and in situ treatments (Liu et al., 2018). The solidification, thermal vitrification, soil washing and landfilling belong to the ex situ group (Khan et al., 2004; Liu et al., 2018). These methods require significant costs and do not guarantee complete remediation of the contaminated sites (Wang et al., 2016). In situ methods are more common and require no special equipment for transportation and processing, but they are only suitable for treating small areas of contaminated soils. They include surface capping, electrokinetic extraction, soil flushing as well as electrical vitrification (Liu et al., 2018). Over the last decade, there has been a significant rise of interest in biological methods of soil treatment, in particular bioremediation and phytobioremediation which also belong to the in situ group (Liu et al., 2018).

Research on approaches to soil bioremediation was intense in the 1990-2000s (Sims et al., 1990; Romantschuk et al., 2000; Brygadyrenko \& Ivanyshyn, 2015; Shulman et al., 2017; Kozak \& Brygadyrenko, 2018). On-site soil bioremediation can decrease sediments, contaminations of groundwater, surface water and nearby agricultural lands, as well as restore the functioning of natural ecosystems in areas of metal ore mining. Bioremediation can be especially promising if used as complex biotechnology including physical, chemical, and biological processes (Sims et al., 1990). However, each method of soil treatment still requires further detail research to improve the efficiency of soil remediation.

Bioremediation comprises bioaugmentation, mycoremediation, cyanoremediation and biostimulation based on the use of microorganisms as the main biotechnological agents and phytoremediation (using of plants) (Mani et al., 2014). Phytobioremediation is one of the most promising and cost-effective methods of clean-up of soils from toxic metals (Mani et al., 2014). According to contemporary researchers, plants have the genetic potential to remove heavy metals from contaminated sites (Marques et al., 
2009; Khan et al., 2021). Plants are able to accumulate soluble forms of toxic metals together with micro- and macronutrients (Mani et al., 2012; Dinu et al., 2020). The use of plants which are resistant to various abiotic stresses (drought, high and low temperatures) in phytoremediation processes may be especially promising for the development of effective environmental biotechnologies. For this purpose, it is promising to use tobacco plants (Nicotiana tabacum L.), which have recently been studied for their resistance to various abiotic factors (Sun et al., 2020). Tobacco plants are resistant to high concentrations of salts and also have molecular genetic determinants of active transport of minerals into plant tissues (Sun et al., 2020). Given their resistance to stress and the ability to accumulate a variety of ions, $N$. tabacum plants are highly promising for phytobioremediation of ecosystems.

However, the transformation of metal compounds in different habitats is carried out not only with the participation of plants, but also with the participation of associated microorganisms of the rhizosphere and rhizoplanes. Microbial communities are the first to contact and interact with metals when they are introduced into the biotopes. Different domains of microorganisms (bacteria and fungi) have already been studied for the ability to remove heavy metals from different environmental niches. Bacteria species Bacillus cereus (Dong et al., 2013), Pseudomonas veronii (Havryliuk et al., 2020), Escherichia coli (Volentini et al., 2011), Cupriavidus gilardii (Yang et al., 2017) etc. as well as fungi Penicillium canescens (Say et al., 2003), Aspergillus versicolor (Taştan et al., 2010) have significant potential for soil remediation. Under the anaerobic conditions, microorganisms are able to synthesize organic acids (metal chelators) that increase the mobility of heavy metals in soils and make them available for active transport and further accumulation in plants. Thus, the development of effective biotechnologies for environment bioremediation needs to apply complex phytomicrobial approaches based on the use of both microorganisms and plants.

\section{Material and methods}

The method of thermodynamic prediction (Tashyrev et al., 2018) was used to theoretically substantiate the mechanisms of interaction between plants and heavy metals. Plants of N. tabacum of Djubek cultivar were used as a plant material for current study (Fig. 1).

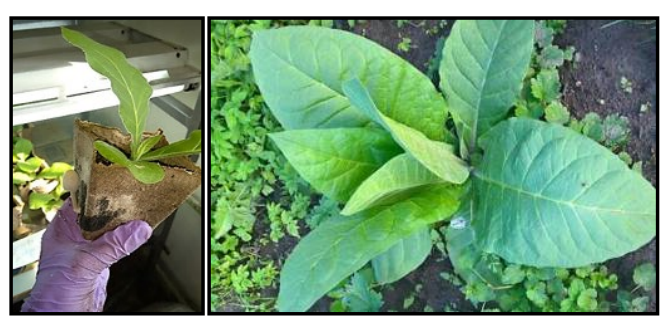

Fig. 1. Nicotiana tabacum L. plants of Djubek cultivar

Before the experiment, we determined soil moisture. For this purpose, $500 \mathrm{~g}$ of moist soil was dried in the constant temperature $\left(105^{\circ} \mathrm{C}\right)$ for 3 hours. After complete drying, the conversion factor of moist soil mass (k) to absolutely dry mass (ADM) was determined. Heavy metal salts, including oxidizing metal $-\mathrm{Cr}^{6+}$ in form $\mathrm{K}_{2} \mathrm{CrO}_{4}$, replace metals $-\mathrm{Co}^{2+}$ $\left(\mathrm{CoCl}_{2}\right)$ and $\mathrm{Ni}^{2+}\left(\mathrm{Ni}\left(\mathrm{NO}_{3}\right)_{2} \cdot 6 \mathrm{H}_{2} \mathrm{O}\right), \mathrm{Cd}^{2+}\left(\mathrm{CdCl}_{2} \cdot 2.5 \mathrm{H}_{2} \mathrm{O}\right)$, and metal of comprehensive action, which combined the negative properties of oxidizing and substitute metals $-\mathrm{Cu}^{2+}\left(\mathrm{CuSO}_{4} \cdot 5 \mathrm{H}_{2} \mathrm{O}\right)$ were used as representative metals. The plants were grown in plastic boxes with soil outdoors in summer. The aqueous solutions of metal salts were added in the boxes after the plants had grown in two months up to the final super-high concentration $-500 \mathrm{mg} / \mathrm{kg}$ of absolutely dry weight of soil. Anaerobic conditions in the soil were achieved by increased watering. Under such conditions, the ground air between the soil particles was replaced by water and led to oxygen deficiency. Accordingly, the metabolism of soil microorganisms shifted towards anaerobiosis, which manifested in decrease in $\mathrm{pH}$ and active synthesis of organic acids, which are chelators of metals and cause their mobilization. Plants were removed from contaminated soil two weeks after the introduction of solutions of metal salts. After removing the tobacco plants, they were thoroughly washed under a stream of cold water to completely clean them from the soil and then dried with filter paper. Assessment of metal-reristant microorganisms was made on example of copper and chromium-resistant microorganisms. It was conducted by cultivation on surface of agar nutrient medium NA (HiMedia Laboratories Pvt. Ltd., India) with the gradient (0-500 ppm) of Cu(II) and (0-350 ppm) $\mathrm{Cr}(\mathrm{VI})$ with a concentration step of $50 \mathrm{ppm}$. For this purpose, solutions of copper sulfate $\left(\mathrm{CuSO}_{4} \cdot 5 \mathrm{H}_{2} \mathrm{O}\right)$ and potassium chromate $\left(\mathrm{K}_{2} \mathrm{CrO}_{4}\right)$ were added to the melted NA medium. Microorganisms were estimated using tenfold dilution method (Taylor, 1962). To obtain isolated colonies, a series of tenfold dilutions of both control and experimental soil samples were prepared in sterile saline $(0.85 \% \mathrm{NaCl})$. Plates with sterile agar medium (HiMedia) and examined metals were pre-prepared and dried. The appropriate dilution of soil $(0.2 \mathrm{~mL})$ was added by a sterile pipette on the surface of the nutrient medium and distributed with a sterile glass Drygalsky spatula. Microorganisms were cultivated at the temperature of $30^{\circ} \mathrm{C}$. The number of microorganisms was determined after 10 days by direct count of colonies in the plates. The number of microbial cells $(\mathrm{M})$ in $1 \mathrm{~mL}$ of suspension was calculated using the formula: $\mathrm{M}=\mathrm{a} \cdot 10 \mathrm{n} / \mathrm{V}$, where $\mathrm{M}$ - the number of colony-forming units in $1 \mathrm{~mL}(\mathrm{CFU} / \mathrm{mL})$; $\mathrm{a}$ the average number of colonies grown on the plate; $10 \mathrm{n}$ - dilution factor; $\mathrm{V}$ - volume of suspension $(\mathrm{mL})$. The amount of microorganisms in milliliters was converted into the amount in grams of absolutely dry soil.

The effect of $\mathrm{Cr}(\mathrm{VI})$ and $\mathrm{Cu}$ (II) on microbiomes of control (without addition of metals) and contaminated soils were determined by comparing the number of colonies of microorganisms on control plates and plates with metals.

The concentrations of metals in soil and plant material (leaves, stems and roots) were determined by atomic absorption method. Preparation of soil and plant samples for atomic absorption analysis was conducted as follows. Soil and plant samples were dried at $20^{\circ} \mathrm{C}$ and then ground in a porcelain mortar. Ashing of plant samples was performed in two stages. The first was carried out on the stove, by gradually adding concentrated $\mathrm{H}_{2} \mathrm{SO}_{4}$. After cessation of white $\mathrm{H}_{2} \mathrm{SO}_{4}$ vapours, the samples were placed in a muffle heated to $250{ }^{\circ} \mathrm{C}$. After two hours, the temperature was brought to $450{ }^{\circ} \mathrm{C}$ and ashed to "grey" ash. The stripping process lasted from 24 to 30 hours, depending on the type of samples. Crucibles with ash were filled with $10 \mathrm{~mL}$ of $\mathrm{HNO}_{3}$ (1:1) and left overnight. The next day, the residues on the crucibles were transported to the clean test tubes. To prepare extracts from the soil, $10 \mathrm{~g}$ of soil samples were added to $250 \mathrm{~mL}$ flasks. The Mora pipette was filled with $100 \mathrm{~mL}$ of ammoniabuffer mixture and left for one day. To prepare the ammonia buffer solution $(\mathrm{pH}=4.8), 54 \mathrm{~mL}$ of glacial acetic acid and $37.5 \mathrm{~mL}$ of $25 \% \mathrm{NH}_{4} \mathrm{OH}$ were added to $400 \mathrm{~mL}$ of $\mathrm{H}_{2} \mathrm{O}$. A day later, the samples were filled with ammonia-buffer solution, filtered through a paper filter into $100 \mathrm{~mL}$ flasks, adjusted to the volume of $100 \mathrm{~mL}$ with ammonia-buffer mixture. The metal concentration was determined using a C-115 M1 spectrometer with a flame atomizer. The efficiency of metal removal $(\mathrm{X}, \%)$ from contaminated soil was determined as the ratio of the total metal content accumulated in the plant $\left(\mathrm{Me}_{\text {plant }}, \mathrm{mg}\right)$ to the initial metal content in the soil $\left(\mathrm{Me}_{\mathrm{soil}}, \mathrm{mg}\right)$ by formula: $\mathrm{X}=\left(\mathrm{Me}_{\mathrm{plane}} \cdot 100 \%\right) / \mathrm{Me}_{\text {soil. }}$

The experiment with microorganisms was performed in triplicate. Standard deviation (SD) and average values (x) were calculated. Significance of difference between average values in the studied $N$. tabacum plants was determined using ANOVA and post-hoc tests (Bonferroni correction).

\section{Results}

The bioremediation potential of microbial communities of the examined soils was studied on the examples of $\mathrm{Cu}(\mathrm{II})$ and $\mathrm{Cr}(\mathrm{VI})$ actions. It was found that the microbial communities of the soil were resistant to compounds of both metals. Thus, the maximum permissible concentration (MPC) of microorganisms in the control and test samples of soils containing $\mathrm{Cu}$ (II) was the same $-500 \mathrm{ppm}$ (Fig. 2). At this concentration, the amount of living microbial cells was high $-(3.8 \pm 0.76) \cdot 10^{3} \mathrm{CFU} / \mathrm{g}$ and (7.2 \pm 0.3$) \cdot 10^{3} \mathrm{CFU} / \mathrm{g}$ (Fig. 2). Thus, the studies revealed high adaptation potential of the soil microorganisms to toxic $\mathrm{Cu}$ (II) compounds, as well as the absence of its negative impact on the microbial communities of the soil in the concentration of $500 \mathrm{ppm}$. We can pressume that the absence of the 
effect of highly toxic copper on microorganisms may indicate that $\mathrm{Cu}^{2+}$ is partially precipitated to insoluble and low-toxic compounds $\left(\mathrm{Cu}(\mathrm{OH})_{2} \downarrow\right.$, $\mathrm{CuCO}_{3} \downarrow$ ) when introduced into soil. The concentrations of soluble $\mathrm{Cu}$ (II) compounds in the soil as well as their detrimental effects decrease during this process.

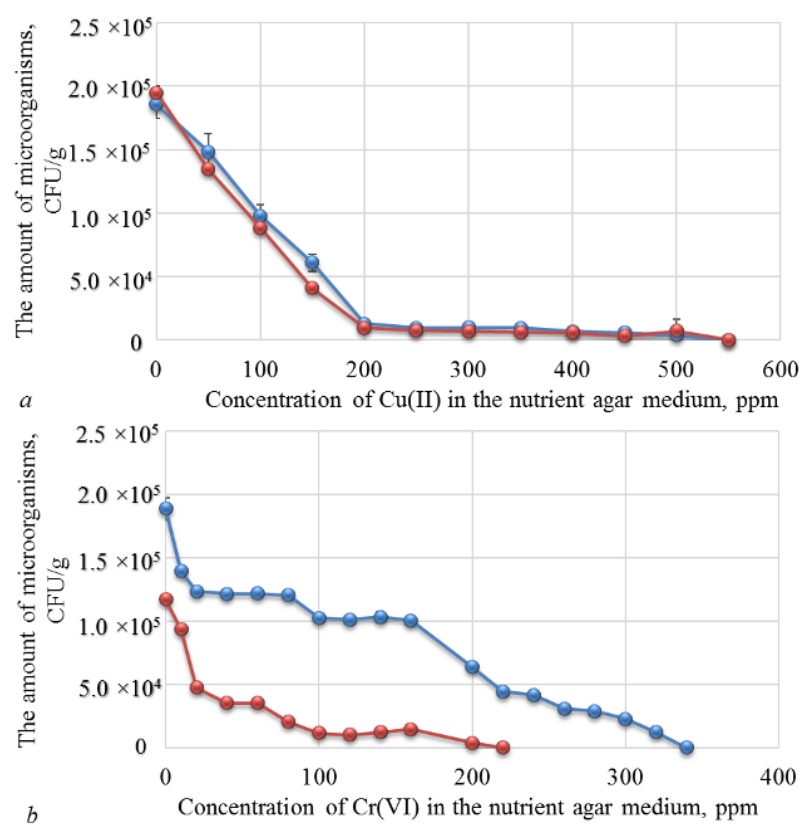

Fig. 2. The effect of toxic soluble copper $(a)$ and chromium $(b)$ compounds on soil microorganisms: blue lines - response of microbiome of control soil; red lines - response of microbiome of metal contaminated soil $(\mathrm{x} \pm \mathrm{SD}, \mathrm{n}=3)$

At the same time, the microorganisms of the studied soil were also resistant to $\mathrm{Cr}(\mathrm{VI})$ compounds. Thus, the MPC of microorganisms of the control soil to $\mathrm{Cr}(\mathrm{VI})$ was $320 \mathrm{ppm}$ (Fig. 2). At this concentration the amount of living microbial cells was very high $-(1.2 \pm 0.19) \cdot 10^{4} \mathrm{CFU} / \mathrm{g}$ (Fig. 2). The microbial communities that were isolated from the experimental soil with $\mathrm{Cr}(\mathrm{VI})$ were less resistant to its compounds (MPC = $200 \mathrm{ppm} \mathrm{Cr}(\mathrm{VI}))$. At MPC concentration, the amount of living microbial cells was (3.9 \pm 0.36$) \cdot 10^{3} \mathrm{CFU} / \mathrm{g}$ (Fig. 2).
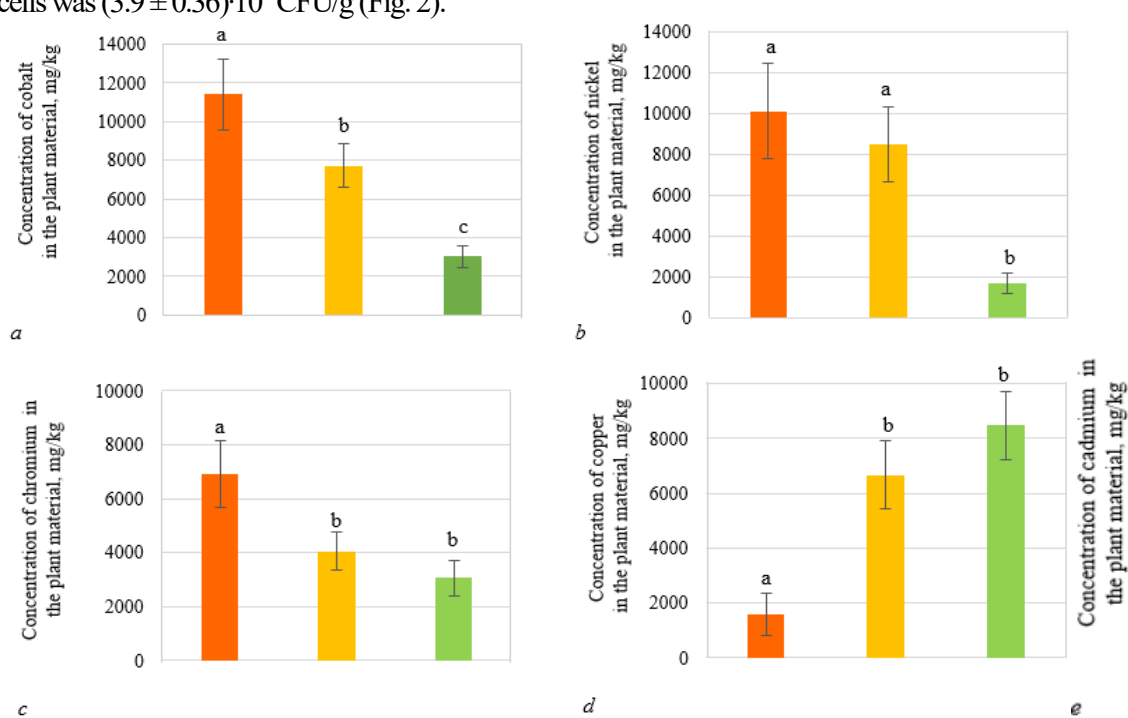

Thus, chromium compounds inhibited the activity of microorganisms directly in the soil, because the results also showed that the total number of living microorganisms in the control soil was 1.6 times higher $((1.9 \pm$ $\left.0.08) \cdot 10^{5} \mathrm{CFU} / \mathrm{g}\right)$ than in the soil the chromium was introduced to $((1.2 \pm$ $0.01) \cdot 10^{5} \mathrm{CFU} / \mathrm{g}$ ). We can pressume that microorganisms showed resistance to toxic metals, so in anaerobic conditions, they probably were not only resistant to metals, but also mobilized them. The mobilization led to the active transport of metal ions into plants and their accumulation in plant tissues. It was shown that heavy metals inhibited the growth of the examined tobacco plants. This was expressed by the necrosis of plant tissues and, ultimately, their complete death (Fig. 3).
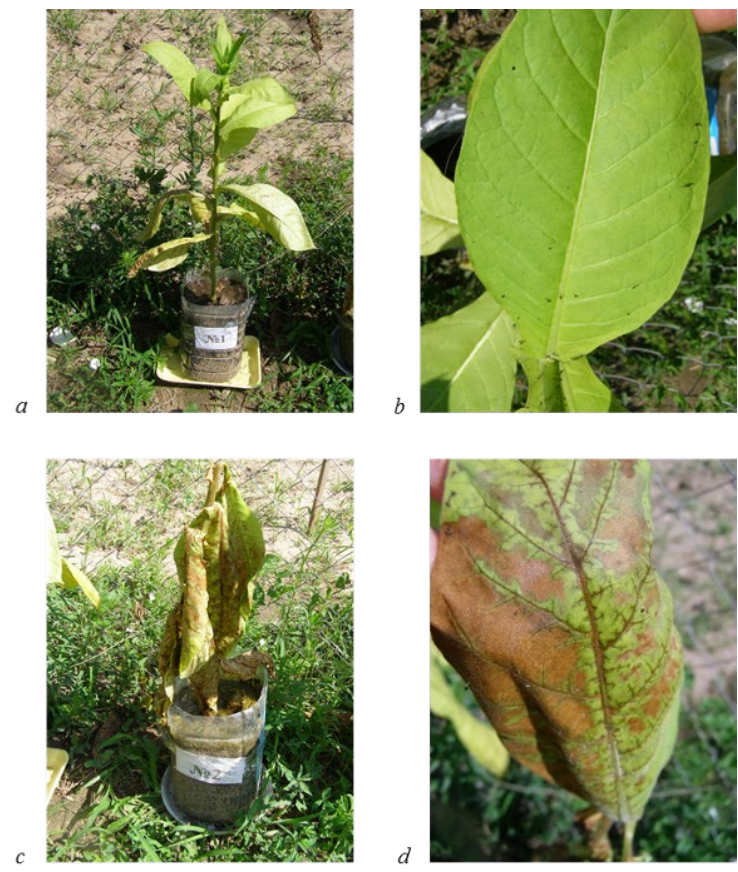

Fig. 3. Detrimental effect of Cr(VI) on Nicotiana tabacum L. plants $a$ - growth before $\mathrm{Cr}(\mathrm{VI})$ addition; $b$ - leaves before $\mathrm{Cr}(\mathrm{VI})$ addition; $c-3$ rd day of growing after $\mathrm{Cr}(\mathrm{VI})$ addition; $d$-areas of leaves affected by $\mathrm{Cr}(\mathrm{VI})$

Fig. 4. Accumulation of cobalt $(a)$, nickel $(b)$, chromium $(c)$, copper $(d)$ and cadmium $(e)$ in the different parts of Nicotiana tabacum L. plants: orange columns - leaves; yellow columns - stems; green columns - roots $(\mathrm{x} \pm \mathrm{SD}, \mathrm{n}=5) ; \mathrm{P}<0.05$ with Bonferroni correction

Despite this, all examined heavy metals accumulated in the plant tissues during 3-7 days before death of plants. Their uptake was observed in all parts of plants - leaves, stems and roots. The highest concentrations of $\mathrm{Co}(\mathrm{II}), \mathrm{Ni}(\mathrm{II}), \mathrm{Cd}(\mathrm{II}), \mathrm{Cr}(\mathrm{VI})$ were found in the leaves and ranged $1,705.8 \pm 424.9$ to $11,405.8 \pm 1,848.2 \mathrm{mg} / \mathrm{kg}$, and $\mathrm{Cu}(\mathrm{II})-$ in the roots, which was $8,491.6 \pm 1,241.2 \mathrm{mg} / \mathrm{kg}$ of absolute dry weight (Fig. 4). The concentration of $\mathrm{Cd}$ in the stems was the lowest and amounted to $545.2 \pm 142.8 \mathrm{mg} / \mathrm{kg}$. The other metals accumulated in the stems of tobacco in much higher quantities. Thus, the concentration of $\mathrm{Cr}(\mathrm{VI})$ was 7.4 times higher, accounting for $4,043.6 \pm 700.9 \mathrm{mg} / \mathrm{kg}$, and the concen- 
tration of $\mathrm{Ni}(\mathrm{II})$ exceeded the concentration of cadmium by as much as 16 times $(8,509.8 \pm 1,828.2 \mathrm{mg} / \mathrm{kg})$. The obtained results indicate a significant potential of plants for application in environmental biotechnologies. It should be noted that all the investigated metals were very toxic and completely destroyed the plants. But, the most toxic of all metals was cadmium. Its smallest amount (from $545.2 \pm 142.8$ to $1,705.8 \pm$ $424.9 \mathrm{mg} / \mathrm{kg}$ ) accumulated in all parts of the plant. In addition, the least intense accumulation of cadmium can be caused by inhibition of growth of plants and blocking of differentiation of the apical meristem of the stems.

It was found that $62.3-79.0 \%$ of the total metal content accumulated in the tobacco leaf $(64.0 \pm 8.3 \%$ of $\mathrm{Ni}$ (II), $62.3 \pm 8.9 \%$ of $\mathrm{Co}$ (II), $69.3 \pm$ $9.4 \%$ of $\mathrm{Cr}(\mathrm{VI}), 79.0 \pm 8.4 \%$ of $\mathrm{Cd}(\mathrm{II}))$. However, the distribution of copper was different from the other metals. Thus, the most copper accumulated in the stems $(53.6 \pm 11.9 \%)$, the least - in the leaves $(10.2 \pm$ $2.3 \%$, Fig. 5). This may be related to slower transport of $\mathrm{Cu}$ (II) into plant tissues. Thus, the plants had no time to accumulate enough metal in the leaves due to rapid damage and death. However, the level of distribution of other metals in the roots was very low. Therefore, only $2.9 \pm 0.6 \%$ $\mathrm{Ni}$ (II), $5.0 \pm 1.5 \% \mathrm{Co}$ (II) and $10.5 \pm 2.5 \% \mathrm{Cd}$ (II) accumulated in the roots.

Efficiency of bioremoval of the examined metals ranged $0.6 \pm 0.2 \%$ to $3.7 \pm 0.6 \%$ (Fig. 6). Given the super-high initial concentration of each of the metals $(500 \mathrm{mg} / \mathrm{kg}$ ), the determined removal efficiency was also high. We may pressume that the bioremoval efficiency will be higher at lower concentration of metals in soil. Cadmium was the most toxic to plants. The rate of plant death under the influence of cadmium was the highest. That is why the concentration of accumulated cadmium in tobacco plants was the lowest.

\section{Discussion}

For the most part, microbiologists study the reaction of microorganisms, and botanists study the reaction of plants in the context of impact of metals on the functioning of biotopes. However, methodologically this is incorrect because metals that ingress into soil interact with both metals and plants. Undoubtedly, the removal of compounds of heavy metals is carried out consistently by microorganisms and plants. After introduction of soluble compounds of metals to the soil, some of the ions precipitate due to interaction with soil compounds. For example, in neutral and slightly alkaline soil, solutions of $\mathrm{Cu}^{2+}$ soluble cation is precipitated: $\mathrm{Cu}^{2+}+2 \mathrm{OH}$ $\rightarrow \mathrm{Cu}(\mathrm{OH})_{2} \downarrow$. But when the soil is flooded, anaerobic microorganisms decrease the $\mathrm{pH}$, leading to fermentation of organic substrates to final products (organic acids) that are metal chelators: $\mathrm{C}_{6} \mathrm{H}_{12} \mathrm{O}_{6}+2 \mathrm{H}_{2} \mathrm{O} \rightarrow$ $2 \mathrm{CH}_{3} \mathrm{COO}^{-}+2 \mathrm{H}^{+}+4 \mathrm{H}_{2}+2 \mathrm{CO}_{2}$. Protons and organic acids convert copper hydroxide into soluble compounds: $\mathrm{Cu}(\mathrm{OH})_{2} \downarrow+2 \mathrm{H}^{+} \rightarrow \mathrm{Cu}^{2+}+$ $2 \mathrm{H}_{2} \mathrm{O}$ and $2 \mathrm{Cu}(\mathrm{OH})_{2} \downarrow+2 \mathrm{CH}_{3} \mathrm{COO}^{-} \rightarrow 2 \mathrm{Cu}\left(\mathrm{CH}_{3} \mathrm{COO}\right)_{2}+\mathrm{H}_{2} \mathrm{O}$. After that plants are able to accumulate soluble metal compounds. Active transport of toxic metals into plants is based on the stereochemical analogy of metals and macroelements. Macroelements are the ions that are necessary for the metabolism of both microorganisms and plants, they are: $\mathrm{K}^{+}, \mathrm{Na}^{+}$ $\mathrm{Mg}^{2+}, \mathrm{Ca}^{2+}, \mathrm{SO}_{4}^{2-}, \mathrm{NO}_{3}^{-}$etc. They are actively absorbed by active transport systems of the plant. Stereochemical analogy is the similarity or equality of the ionic radii of toxic metals and macroelements. For example, $\mathrm{Cu}^{2+}$ is a stereochemical analogue of $\mathrm{Mg}^{2+}$, for they have the same ionic radius, equaling $0.075 \mathrm{~nm}$. That is why acceptor and transport systems of plants are mistaken and "swallow" toxic metal $\mathrm{Cu}^{2+}$ together with nesessary macroelement $\mathrm{Mg}^{2+}$. All other investigated heavy metals are also stereochemical analogues of macroelements. For example, chromate $\left(\mathrm{CrO}_{4}^{2-}\right)$ is the analogue of sulfate $\left(\mathrm{SO}_{4}^{2-}\right)$, they have the ionic radii of $0.3 \mathrm{~nm}$ and therefore chromate is transported and accumulated by plants together with sulfate. Thus, we develop the general theoretical approach to choose the optimal pathways of interaction microorganisms and plants with heavy metals.

Our approach is confirmed by numerous publications involving both microorganisms and plants in the ability to transform metal compounds. It has long been known that macroelements are necessary for plant metabolism (Pogrzeba et al., 2018) and are actively absorbed by plant transport systems (Tripathi et al., 2014). By the mechanism of stereochemical analogy, metal ions are absorbed by mechanisms of common transport with macroelements. Metals can exist in the soil as discrete particles or can be associated with different soil components, including free metal ions and soluble metal compounds in the soil solution, exchangeable ions sorbed onto inorganic solid phase surfaces, nonexchangeable ions and precipitated or insoluble inorganic metal compounds (carbonates, phosphates, etc.), metals complexed by soluble or insoluble organic material, and metals bound in silicate minerals (Marques et al., 2009). Microorganisms are those mobilizing insoluble metal compounds. Therefore, the plants are able to bioremove them from the soil.
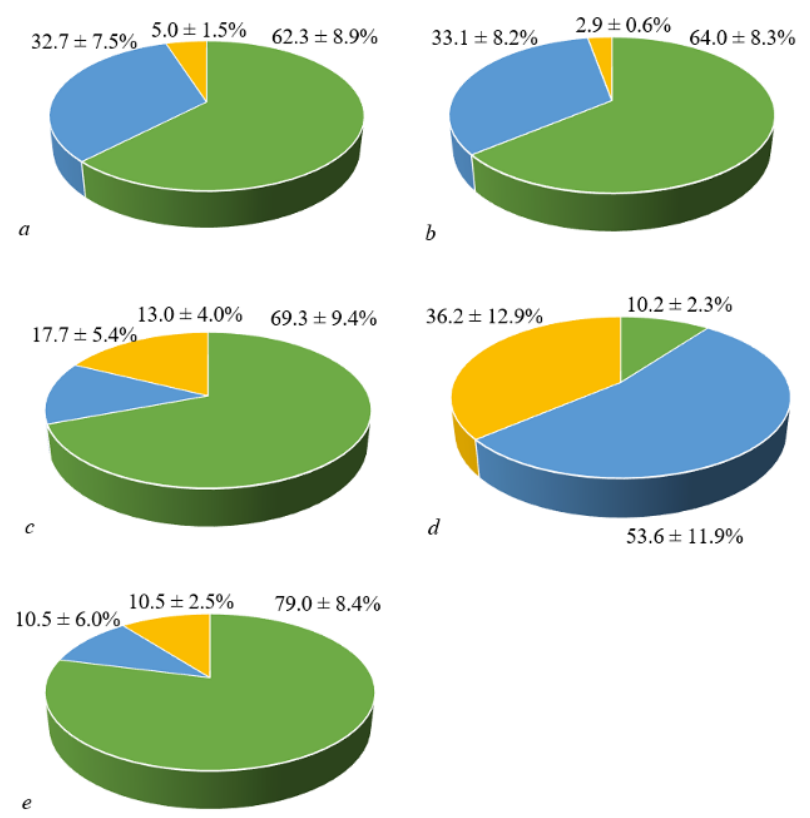

Fig. 5. Distribution of cobalt (a), nickel (b), chromium (c), copper (d), cadmium $(e)$ in different parts of plants: green sections - leaves; blue sections - stems; yellow sections - roots $(\mathrm{x} \pm \mathrm{SD}, \mathrm{n}=5)$

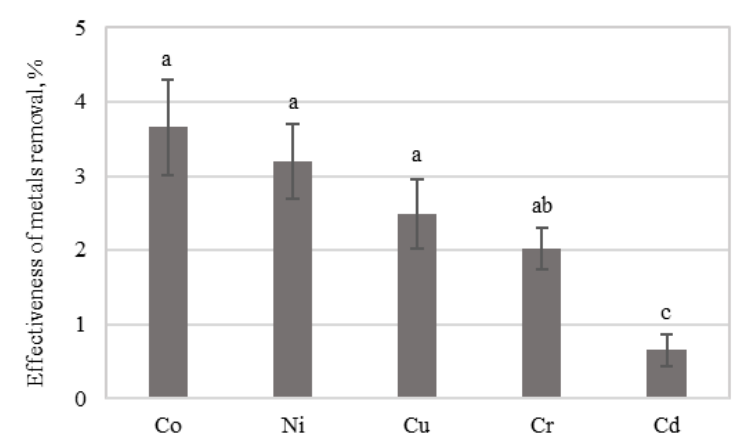

Fig. 6. Effectiveness of the metals removal by Nicotiana tabacum $\mathrm{L}$. plants $(\mathrm{x} \pm \mathrm{SD}, \mathrm{n}=5) ; \mathrm{P}<0.05$ with Bonferroni correction

Heavy metals are among the most hazardous pollutants of the environment. The main sources of metal pollution are industrial activities (Rajbanshi, 2009), metal ore mining sites (Bhuiyan et al., 2010), and uncontrolled overuses of pesticides (Husak, 2015). Contamination of such heavy metals as $\mathrm{Pb}, \mathrm{Zn}, \mathrm{Cu}, \mathrm{Mn}, \mathrm{Ni}$, and $\mathrm{Cr}$ was detected in soils of the Roztocze National Park forest (SE Poland). Content of metals in the surface layers exceeded their content in the parent material by tens of times. This distribution of heavy metals in the studied soils was related to the influence of both local and distant sources of anthropogenic emission (originating from transport as well as emissions of pollutants from distant industrial centres, accumulation of particulate deposition from iron ore transported by the railway). In this anthropogenic ecosystem, the concentration of $\mathrm{Pb}$ reached $238.3 \mathrm{mg} / \mathrm{kg}$, and $\mathrm{Cu}-62 \mathrm{mg} / \mathrm{kg}$ (Mazurek et al., 2017).

The territories of Ukraine are also significantly affected by man-made load and extremely saturated with industrial and mining enterprises (there are more than 1.5 thousand of them), and have an extensive network (more than 165 thousand $\mathrm{km}$ ) of roads (Dovgalyuk, 2013). High concentrations of heavy metals were found in the soils of urban areas of almost all 
of Central and South-Eastern Ukraine. According to the State Statistics Committee of Ukraine for 2009-2010, the soils of the cities of Vinnytsia, Mariupol and Poltava were the most polluted (Dovgalyuk, 2013). Significant pollution with heavy metals was also observed in the areas of metal ore deposits and in places of their industrial mining (Tang et al., 2017). Densely populated regions of Nigeria are places of ecological disasters. Thus, the soils of the uncontrolled mining site at Dareta village, Zamfara, Nigeria are moderately polluted with $\mathrm{Cr}, \mathrm{Ni}, \mathrm{Pb}, \mathrm{Fe}, \mathrm{Cu}, \mathrm{Cd}$, and $\mathrm{Mn}$. The results shows that there is increased concentration of $\mathrm{Cr}(14 \mathrm{mg} / \mathrm{kg}$ of soil) in one of the resident soils of investigated site of Dareta village (Sulaiman et al., 2019). Results of Ukah et al. (2019) revealed that $\mathrm{Cu}$ is the most prevalent heavy metal, contaminating $85.7 \%$ of the analyzed samples of ground water of an industrial area of Lagos, Nigeria (Ukah et al., 2019).

The studies already revealed that plants growing in contaminated areas are able to accumulate heavy metals in plant biomass (Dinu et al., 2020). The patterns of uptake of heavy metals by plants of Ocimum basilicum $\mathrm{L}$. were investigated. The metals concentrated differently in the plant organs: $\mathrm{Cd}, \mathrm{Co}, \mathrm{Cr}$, and $\mathrm{Pb}$ accumulated in roots, while $\mathrm{Cu}, \mathrm{Ni}$, and $\mathrm{Zn}$ concentrated in flowers. Excessed toxic levels of $\mathrm{Cr}$ and $\mathrm{Pb}$ were in the roots. Basil flowers intensively accumulated $\mathrm{Cu}$ and $\mathrm{Zn}$, the concentrations of which was 16 and $80 \mathrm{mg} / \mathrm{kg}$ respectively. $\mathrm{Co}$ and $\mathrm{Pb}$ concentrated intensively in the roots, equaling 2.6 and $28 \mathrm{mg} / \mathrm{kg}$ respectively. This study revealed that Ocimum basilicum L. plants in metal stress conditions had a great phytostabilization potential (Dinu et al., 2020). Dhiman et al. (2017) in their study demonstrated the hyperaccumulation capacity of sunflower (Helianthus annuus L.) biomass by cultivating these plants in various concentrations of metal contaminants. Sunflowers were grown in soils contaminated with high levels of heavy metals (10-2000 mg/kg dry soil). In the case of $\mathrm{Ni}, \mathrm{As}$, and $\mathrm{Cd}$ in low concentrations $(10-100 \mathrm{mg} / \mathrm{kg}$ dry soil), $\mathrm{Cd}^{2+}$ (161 mg/kg dry weight) accumulated the most in sunflower leaves and flowers, whereas the stems concentrated only $78.4 \mathrm{mg} / \mathrm{kg}$ of dry weight. Similarly, for $\mathrm{Ni}$ and As, the flowers and leaves were observed to have higher phytoremediation capacity than the stems. Thus, the concentration of $\mathrm{Ni}$ in leaves and flowers was $99.1 \mathrm{mg} / \mathrm{kg}$ of biomass at an initial concentration in soil $-100 \mathrm{mg} / \mathrm{kg}$. The levels of $\mathrm{Cu}$ and $\mathrm{Cd}$ accumulation in the leaves and flowers were also high, measuring $75.3 \mathrm{mg} / \mathrm{kg}$ and $161 \mathrm{mg} / \mathrm{kg}$ during growth in contaminated soil containing $450 \mathrm{mg} / \mathrm{kg}$ $\mathrm{Cu}$ and $100 \mathrm{mg} / \mathrm{kg} \mathrm{Cd}$, respectively (Dhiman et al., 2017). Plants of Brassica juncea $\mathrm{L}$. were identified as potential candidates for soil bioremediation. The studies revealed that Indian mustard accumulated $\mathrm{Cd}$ and $\mathrm{Pb}$ in the shoots and roots in the range of concentrations of $2.43 \pm 0.00$ to $0.31 \pm$ $0.02 \mathrm{mg} / \mathrm{kg}$ and $2.94 \pm 0.05$ to $0.44 \pm 0.03$ and $5.33 \pm 0.76$ to $0.47 \pm 0.20$ and $3.78 \pm 0.06$ to $0.16 \pm 0.08 \mathrm{mg} / \mathrm{kg}$ (Gurajala et al., 2019).

Tobacco plants (Nicotiana tabacum L.) have already begun to be studied as environmentally friendly, as they are tolerant to abiotic stresses and have the genetic potential for bioremoval of salts and metals ions from soils (Sun et al., 2020). Despite the ability to accumulate metals, tobacco plants were adversely affected by vanadium. Vanadium induced oxidative stress in the growth of tobacco, as indicated by rapidly increased foliar $\mathrm{H}_{2} \mathrm{O}_{2}$ and $\mathrm{O}_{2}^{-}$. Tobacco growth was significantly inhibited at $\geq 2.0 \mathrm{mg} / \mathrm{L}$ $\mathrm{V}$ dosages. However, the plant can effectively alleviate the oxidative stress induced by vanadium by activating its antioxidant defense system (enzyme and non-enzyme). Thereby, the plant has the potential to be used as a phytostabilizer for in situ remediation in the vanadium-contaminated environment. Thus, the total uptake amounting to 4.4, 14.6, 65.3, 157.9, and $293.5 \cdot 10^{-3} \mathrm{mg}$ of vanadium per plant were obtained at $0.0,0.1,0.5$, 2.0, and $4.0 \mathrm{mg} / \mathrm{L} \mathrm{V}$ treatment, respectively (Wu et al., 2021). Molecular genetic approaches are used to increase the resistance of tobacco plants to heavy metals. Thus, the AtACR2 gene (arsenic reductase 2) of Arabidopsis thaliana was introduced into the genome of tobacco (Nicotiana tabacum, var Sumsun). The results revealed that the transgenic tobacco plants are more resistant to arsenic compared with wild-growing plants. These plants can grow on culture medium containing $200 \mu \mathrm{M}$ arsenate. The arsenic content in the roots of transgenic tobacco plants was significantly higher $(2,400 \mu \mathrm{g} / \mathrm{g} \mathrm{d}$. wt.) than that $(2,100 \mu \mathrm{g} / \mathrm{g} \mathrm{d}$. wt.) observed in roots of wild plants (Nahar et al., 2017).

Despite the high potential of different plant species for bioremediation of the environment, we argue that an integrated approach is needed to develop effective environmental biotechnologies. Thus, the transformation of metal compounds in the soil occurs not only with the participation of plants, but also with the participation of associated microorganisms of the rhizosphere and rhizoplanes (Marques et al., 2009; Li et al., 2019). The participation of microorganisms in the transformation of metal compounds in soils is both their mobilization by metabolite chelators and immobilization (reduction to insoluble non-toxic compounds, accumulation as well as precipitation in the form of insoluble oxides, hydroxides, carbonates, sulfides etc.). Because of the ability to mobilize metals in soil, microorganisms make them available to plnats. Therefore, it is necessary to study the mechanisms of interaction of metals with both plants and microorganisms. It was shown that Aspergillus versicolor was able to accumulate compounds of $\mathrm{Ni}$ (II), $\mathrm{Cu}$ (II) and $\mathrm{Cr}$ (VI at the initial concentration of $50 \mathrm{ppm}$. Optimum $\mathrm{pH}$ values of the maximum heavy metal bioaccumulation were determined to equal 6 for $50 \mathrm{ppm}$ of $\mathrm{Cr}(\mathrm{VI}), \mathrm{Ni}(\mathrm{II})$ and 5 for $\mathrm{Cu}$ (II) ions with $99.9 \%, 30.1 \%$ and $29.1 \%$ removal yield, respectively (Taştan et al., 2010). Also, different types of microorganisms are able to reduce heavy metal compounds, which can also be used in soil bioremediation. For example, in the reduction reaction of soluble chromium compounds, trivalent chromium hydroxide $\left(\mathrm{CrO}_{4}{ }^{2-} \rightarrow \mathrm{Cr}(\mathrm{OH})_{3} \downarrow\right)$ is insoluble in water and organic acids, and soluble only in concentrated mineral acids. The solubility level of chromium compounds at $25^{\circ} \mathrm{C}$ is $6.3 \cdot 10^{-31}$. Therefore, during cleanup of soil from toxic $\mathrm{Cr}$ (VI) compounds, it is optimal to convert it into insoluble and non-toxic hydroxide directly in soils, because moisture and microbial exometabolites are unable to mobilize it. For example, Pseudomonas stutzeri was able to reduce $\mathrm{Cr}(\mathrm{VI})$ compounds (Sathishkumar et al., 2017). Bacillus brevis was resistant to elevated $\mathrm{Cr}(\mathrm{VI})$ levels and may potentially reduce it in short time from in the environment where other metal ions are also present in addition to chromium ions (Verma et al., 2009). According to the thermodynamic prognosis, the optimal way of soil bioremediation is the mobilization (bioleaching) of heavy metals by microorganisms with subsequent uptake by plants. Therefore, the study of the mechanisms of metal resistance and their microbial mobilization is extremely important. The ability to mobilize metals is used not only in environmental but also in industrial biotechnology for extraction of metal ores. For example, extremophilic metal-resistant bacteria (Acidithiobacillus ferrooxidans) and archaea (Sulfolobus metallicus) are used in industrial biomining processes to extract copper, gold and other metals (Orell et al., 2010). Despite the presence of a significant amount of separate studies on the use of both microorganisms and plants in ecological biotechnologies, the mechanisms of joint removal of heavy metals from soils by phytomicrobial communities are almost unexplored.

\section{Conclusion}

Thus, the basic points of the thermodynamic prognosis about the possibility of interaction between phytomicrobial consortia and heavy metals were experimentally confirmed. Quantitative patterns of distribution of toxic metals in plant tissues of Nicotiana tabacum L. plants were experimentally studied. The studies revealed that despite the high initial concentration of metals, rates of damage and death of plants, they accumulate them in the tissues in extremely high concentrations. The high adaptation potential of soil microorganisms to $\mathrm{Cu}(\mathrm{II})$ and $\mathrm{Cr}(\mathrm{VI})$ were demonstrated. We can pressume that in anaerobic conditions microorganisms mobilize heavy metals, which then are absorbed by plants. The obtained results can serve as the basis for the further development of environmental biotechnologies for clean-up of contaminated soils from compounds of heavy metal.

The study was funded within the fundamental research theme of the National Academy of Sciences of Ukraine on the subject \#06.80 "Properties of extremophilic microorganisms and their biotechnological potential" in 2016-2020.

\section{References}

Aleksandra, S.-N. (2011). Phytotechnologies: Importance in remediation of heavy metal-contaminated soils. In: Khan, M., Zaidi, A., Goel, R., \& Musarrat, J. (Eds.). Biomanagement of metal-contaminated soils. Environmental Pollution, Springer, Dordrecht. Pp. 277-295.

Bhuiyan, M. A. H., Parvez, L., Islam, M. A., Dampare, S. B., \& Suzuki, S. (2010). Heavy metal pollution of coal mine-affected agricultural soils in the northern part of Bangladesh. Joumal of Hazardous Materials, 173, 384-392. 
Brygadyrenko, V., \& Ivanyshyn, V. (2015). Changes in the body mass of Megaphyllum kievense (Diplopoda, Julidae) and the granulometric composition of leaf litter subject to different concentrations of copper. Joumal of Forest Science, 61(9), 369-376.

Dhiman, S. S., Zhao, X., Li, J., Kim, D., Kalia, V. C., Kim, I., Kim, J. Y., \& Lee, J. (2017). Metal accumulation by sunflower (Helianthus annus L.) and the efficacy of its biomass in enzymatic saccharification. PLoS One, 12(4), e0175845.

Dinu, C., Vasile, G.-G., Buleandra, M., Popa, D. E., Gheorghe, S., \& Ungureanu, E.M. (2020). Translocation and accumulation of heavy metals in Ocimum basilicum L. plants grown in a mining-contaminated soil. Journal of Soils and Sediments, 20(4), 2141-2154.

Dong, G., Wang, Y., Gong, L., Wang, M., Wang, H., He, N., Zheng, Y., \& Li, Q. (2013). Formation of soluble Cr(III) end-products and nanoparticles during $\mathrm{Cr}(\mathrm{VI})$ reduction by Bacillus cereus strain XMCr-6. Biochemical Engineering Journal, 70, 166-172.

Dovgalyuk, A. (2013). Environmental pollution by toxic metals and its indication by plant test systems. Studia Biologica, 7(1), 197-204.

Fashola, M. O., Ngole-Jeme, V. M., \& Babalola, O. O. (2016). Heavy metal pollution from gold mines: Environmental effects and bacterial strategies for resistance. International Journal of Environmental Research and Public Health, 13(11), 1047.

Gurajala, H. K., Cao, X., Tang, L., Ramesh, T. M., Lu, M., \& Yang, X. (2019). Comparative assessment of Indian mustard (Brassica juncea L.) genotypes for phytoremediation of $\mathrm{Cd}$ and $\mathrm{Pb}$ contaminated soils. Environmental Pollution, 254, 113085.

Havryliuk, O., Hovorukha, V., Patrauchan, M., Youssef, N. H., \& Tashyrev, O. (2020). Draft whole genome sequence for four highly copper resistant soil isolates Pseudomonas lactis strain UKR1, Pseudomonas panacis strain UKR2, and Pseudomonas veronii strains UKR3 and UKR4. Current Research in Microbial Sciences, $1,44-52$.

Husak, V. (2015). Copper and copper-containing pesticides: Metabolism, toxicity and oxidative stress. Journal of Vasyl Stefanyk Precarpathian National University, 2(1), 38-50.

Khan, F. I., Husain, T., \& Hejazi, R. (2004). An overview and analysis of site remediation technologies. Joumal of Environmental Management, 71(2), 95-122.

Khan, Z. I., Ugulu, I., Zafar, A., Mehmood, N., Bashir, H., Ahmad, K., \& Sana, M. (2021). Biomonitoring of heavy metals accumulation in wild plants growing at Soon valley, Khushab, Pakistan. Pakistan Joumal of Botany, 53(1), 247-252.

Kozak, V. M., \& Brygadyrenko, V. V. (2018). Impact of cadmium and lead on Megaphyllum kievense (Diplopoda, Julidae) in a laboratory experiment. Biosystems Diversity, 26(2), 128-131.

Li, C., Zhou, K., Qin, W., Tian, C., Qi, M., \& Yan, X. (2019). A review on heavy metals contamination in soil: Effects, sources, and remediation techniques, soil and sediment contamination. An International Journal, 28(4), 380-394.

Li, Z., Ma, Z., V. D. Kuijp, T. J., Yuan, Z., \& Huang, L. (2014). A review of soil heavy metal pollution from mines in China: Pollution and health risk assessment. Science of the Total Environment, 468-469, 843-853.

Liu, L., Li, W., Song, W., \& Guo, M. (2018). Remediation techniques for heavy metal-contaminated soils: Principles and applicability. Science of the Total Environment, 633, 206-219.

Mani, D., \& Kumar, C. (2014). Biotechnological advances in bioremediation of heavy metals contaminated ecosystems: An overview with special reference to phytoremediation. International Journal of Environmental Science and Technology, 11(3), 843-872.

Mani, D., Sharma, B., Kumar, C., Pathak, N., \& Balak, S. (2012). Phytoremediation potential of Helianthus annuus $\mathrm{L}$ in sewage-irrigated indo-gangetic alluvial soils. International Joumal of Phytoremediation, 14(3), 235-246.

Marques, A. P. G. C., Rangel, A. O. S. S., \& Castro, P. M. L. (2009). Remediation of heavy metal contaminated soils: Phytoremediation as a potentially promising clean-up technology. Critical Reviews in Environmental Science and Technology, 39(8), 622-654.

Masindi, V., \& Muedi, K. L. (2018). Environmental contamination by heavy metals. In: El-Din, H., Saleh, M., \& Aglan, R. F. (Eds). Heavy metals. IntechOpen. Pp. 115-133.

Mazurek, R., Kowalska, J., Gąsiorek, M., Zadrożny, P., Józefowska, A., Zaleski, T., Kepka, V., Tymczuk, M., \& Orłowska, K. (2017). Assessment of heavy metals contamination in surface layers of Roztocze National Park forest soils (SE Poland) by indices of pollution. Chemosphere, 2016, 1-12.

Nahar, N., Rahman, A., Nawani, N. N., Ghosh, S., \& Mandal, A. (2017). Phytoremediation of arsenic from the contaminated soil using transgenic tobacco plants expressing ACR2 gene of Arabidopsis thaliana. Journal of Plant Physiology, $218(8), 121-126$
Orell, A., Navarro, C. A., Arancibia, R., Mobarec, J. C., \& Jerez, C. A. (2010). Life in blue: Copper resistance mechanisms of bacteria and Archaea used in industrial biomining of minerals. Biotechnology Advances, 28(6), 839-848.

Pogrzeba, M., Rusinowski, S., \& Krzyżak, J. (2018). Macroelements and heavy metals content in energy crops cultivated on contaminated soil under different fertilization - case studies on autumn harvest. Environmental Science and Pollution Research, 25(12), 12096-12106.

Rajbanshi, A. (2009). Study on heavy metal resistant bacteria in Guheswori Sewage Treatment Plant. Our Nature, 6(1), 52-57.

Romantschuk, M., Sarand, I., Petänen, T., Peltola, R., Jonsson-Vihanne, M., Koivula, T., Yrjälä, K., \& Haahtela, K. (2000). Means to improve the effect of in situ bioremediation ofcontaminated soil. Environmental Pollution, 107(2), 179-185.

Sathishkumar, K., Murugan, K., Benelli, G., Higuchi, A., \& Rajasekar, A. (2017). Bioreduction of hexavalent chromium by Pseudomonas stutzeri L1 and Acinetobacter baumannii L2. Annals of Microbiology, 67(1), 91-98.

Say, R., Yilmaz, N., \& Denizli, A. (2003). Removal of heavy metal ions using the fungus Penicillium canescens. Adsorption Science and Technology, 21(7), 643-650.

Shulman, M. V., Pakhomov, O. Y., \& Brygadyrenko, V. V. (2017). Effect of lead and cadmium ions upon the pupariation and morphological changes in Calliphora vicina (Diptera, Calliphoridae). Folia Oecologica, 44(1), 28-37.

Sims, J. L., Sims, R. C., \& Matthews, J. E. (1990). Approach to bioremediation of contaminated soil. Hazardous Waste and Hazardous Materials, 7(2), 117-149.

Sulaiman, M. B., Salawu, K., \& Barambu, A. U. (2019). Assessment of concentrations and ecological risk of heavy metals at resident and remediated soils of uncontrolled mining site at Dareta Village, Zamfara, Nigeria. Joumal of Applied Sciences and Environmental Management, 23(1), 189-193.

Sun, H., Sun, X., Wang, H., \& Ma, X. (2020). Advances in salt tolerance molecular mechanism in tobacco plants. Hereditas, 157(1), 1-6.

Sun, Z., Xie, X., Wang, P., Hu, Y., \& Cheng, H. (2018). Heavy metal pollution caused by small-scale metal ore mining activities: A case study from a polymetallic mine in South China. Science of the Total Environment, 639, 217-227.

Tang, Z., Chai, M., Cheng, J., Jin, J., Yang, Y., Nie, Z., \& Huang, Q. (2017). Ecotoxicology and environmental safety contamination and health risks of heavy metals in street dust from a coal-mining city in Eastern China. Ecotoxicology and Environmental Safety, 138(2016), 83-91.

Tashyrev, O., Govorukha, V., Suslova, O., \& Tashyreva, H. (2018). Thermodynamic prediction for development of novel environmental biotechnologies and valuable products from waste obtaining. Ecological Engineering and Environment Protection, 2018(1), 24-35.

Taștan, B. E., Ertuğrul, S., \& Dönmez, G. (2010). Effective bioremoval of reactive dye and heavy metals by Aspergillus versicolor. Bioresource Technology, 101(3), 870-876.

Taylor, J. (1962). The estimation of numbers of bacteria by tenfold dilution series. Joumal of Applied Bacteriology, 25(1), 54-61.

Tripathi, D. K., Singh, V., Chauhan, D., Prasad, S., \& Dubey, N. K. (2014). Recent advances and future prospective. In: Ahmad, P., Wani, M., Azooz, M., \& Phan Tran, L. S. (Eds.). Improvement of crops in the era of climatic changes. Springer, New York. Pp. 197-216.

Ukah, B. U., Egbueri, J. C., Unigwe, C. O., \& Ubido, O. E. (2019). Extent of heavy metals pollution and health risk assessment of groundwater in a densely populated industrial area, Lagos, Nigeria. International Joumal of Energy and Water Resources, 3, 291-303.

Verma, T., Garg, S. K., \& Ramteke, P. W. (2009). Genetic correlation between chromium resistance and reduction in Bacillus brevis isolated from tannery effluent. Joumal of Applied Microbiology, 107(5), 1425-1432.

Volentini, S. I., Farías, R. N., Rodríguez-Montelongo, L., \& Rapisarda, V. A. (2011). $\mathrm{Cu}$ (II)-reduction by Escherichia coli cells is dependent on respiratory chain components. BioMetals, 24(5), 827-835.

Wang, G., Zhang, S., Xu, X., Zhong, Q., Zhang, C., Jia, Y., Li, T., Deng, O., \& Li, Y, (2016). Heavy metal removal by GLDA washing: Optimization, redistribution, recycling, and changes in soil fertility. Science of the Total Environment, 569 570, 557-568.

Wu, Z., Yang, J., Zhang, Y., Wang, C., \& Guo, S. (2021). Growth responses, accumulation, translocation and distribution of vanadium in tobacco and its potential in phytoremediation. Ecotoxicology and Environmental Safety, 207, 111297.

Xiao, R., Wang, S., Li, R., Wang, J. J., \& Zhang, Z. (2017). Soil heavy metal contamination and health risks associated with artisanal gold mining in Tongguan, Shaanxi, China. Ecotoxicology and Environmental Safety, 141, 17-24.

Yang, Y., Hu, M., Zhou, D., Fan, W., Wang, X., \& Huo, M. (2017). Bioremoval of $\mathrm{Cu}^{2+}$ from CMP wastewater by a novel copper-resistant bacterium Cupriavidus gilardii CR3: Characteristics and mechanisms. RSC Advances, 7(30), 1879318802 . 